NASA/TM-2010-216068

\title{
Investigation of Loop Heat Pipe Survival and Restart After Extreme Cold Environment Exposure
}

\section{Eric Golliher}

Glenn Research Center, Cleveland, Ohio

Jentung Ku

Goddard Space Flight Center, Greenbelt, Maryland

Anthony Licari

Ohio Aerospace Institute, Brook Park, Ohio

James Sanzi

Sest, Inc., Middleburg Heights, Ohio 


\section{NASA STI Program . . . in Profile}

Since its founding, NASA has been dedicated to the advancement of aeronautics and space science. The NASA Scientific and Technical Information (STI) program plays a key part in helping NASA maintain this important role.

The NASA STI Program operates under the auspices of the Agency Chief Information Officer. It collects, organizes, provides for archiving, and disseminates NASA's STI. The NASA STI program provides access to the NASA Aeronautics and Space Database and its public interface, the NASA Technical Reports Server, thus providing one of the largest collections of aeronautical and space science STI in the world. Results are published in both non-NASA channels and by NASA in the NASA STI Report Series, which includes the following report types:

- TECHNICAL PUBLICATION. Reports of completed research or a major significant phase of research that present the results of NASA programs and include extensive data or theoretical analysis. Includes compilations of significant scientific and technical data and information deemed to be of continuing reference value. NASA counterpart of peer-reviewed formal professional papers but has less stringent limitations on manuscript length and extent of graphic presentations.

- TECHNICAL MEMORANDUM. Scientific and technical findings that are preliminary or of specialized interest, e.g., quick release reports, working papers, and bibliographies that contain minimal annotation. Does not contain extensive analysis.

- CONTRACTOR REPORT. Scientific and technical findings by NASA-sponsored contractors and grantees.
- CONFERENCE PUBLICATION. Collected papers from scientific and technical conferences, symposia, seminars, or other meetings sponsored or cosponsored by NASA.

- SPECIAL PUBLICATION. Scientific, technical, or historical information from NASA programs, projects, and missions, often concerned with subjects having substantial public interest.

- TECHNICAL TRANSLATION. Englishlanguage translations of foreign scientific and technical material pertinent to NASA's mission.

Specialized services also include creating custom thesauri, building customized databases, organizing and publishing research results.

For more information about the NASA STI program, see the following:

- Access the NASA STI program home page at http://www.sti.nasa.gov

- E-mail your question via the Internet to help@ sti.nasa.gov

- Fax your question to the NASA STI Help Desk at $443-757-5803$

- Telephone the NASA STI Help Desk at 443-757-5802

- Write to: NASA Center for AeroSpace Information (CASI) 7115 Standard Drive Hanover, MD 21076-1320 
NASA/TM-2010-216068

HT2009-88509

\section{Investigation of Loop Heat Pipe Survival and Restart After Extreme Cold Environment Exposure}

\section{Eric Golliher}

Glenn Research Center, Cleveland, Ohio

Jentung Ku

Goddard Space Flight Center, Greenbelt, Maryland

Anthony Licari

Ohio Aerospace Institute, Brook Park, Ohio

James Sanzi

Sest, Inc., Middleburg Heights, Ohio

Prepared for the

Summer Heat Transfer Conference (HT2009)

sponsored by the American Society of Mechanical Engineers

San Francisco, California, July 19-23, 2009

National Aeronautics and

Space Administration

Glenn Research Center

Cleveland, Ohio 44135 


\section{Acknowledgments}

The advice of Dan Butler and Mark Kobel of Goddard Space Flight Center (GSFC) were critical to the success of this investigation. The authors also wish to thank Timothy Jin, summer intern with the National Center for

Space Exploration Research, for his help with data acquisition during testing and for his idea of using dry ice to cool the loop heat pipe (LHP) condenser.

Trade names and trademarks are used in this report for identification only. Their usage does not constitute an official endorsement, either expressed or implied, by the National Aeronautics and Space Administration.

Level of Review: This material has been technically reviewed by technical management.

Available from

NASA Center for Aerospace Information 7115 Standard Drive

Hanover, MD 21076-1320
National Technical Information Service 5285 Port Royal Road Springfield, VA 22161

Available electronically at http://gltrs.grc.nasa.gov 


\title{
Investigation of Loop Heat Pipe Survival and Restart After Extreme Cold Environment Exposure
}

\author{
Eric Golliher \\ National Aeronautics and Space Administration \\ Glenn Research Center \\ Cleveland, Ohio 44135 \\ Jentung $\mathrm{Ku}$ \\ National Aeronautics and Space Administration \\ Goddard Space Flight Center \\ Greenbelt, Maryland 20771 \\ Anthony Licari \\ Ohio Aerospace Institute \\ Brook Park, Ohio 44142 \\ James Sanzi \\ Sest, Inc. \\ Middleburg Heights, Ohio 44130
}

\begin{abstract}
NASA plans human exploration near the South Pole of the Moon, and other locations where the environment is extremely cold. This paper reports on the heat transfer performance of a loop heat pipe (LHP) exposed to extreme cold under the simulated reduced gravitational environment of the Moon. A common method of spacecraft thermal control is to use a LHP with ammonia working fluid. Typically, a small amount of heat is provided either by electrical heaters or by environmental design, such that the LHP condenser temperature never drops below the freezing point of ammonia. The concern is that a liquid-filled, frozen condenser would not restart, or that a thawing condenser would damage the tubing due to the expansion of ammonia upon thawing.

This paper reports the results of an experimental investigation of a novel approach to avoid these problems. The LHP compensation chamber (CC) is conditioned such that all the ammonia liquid is removed from the condenser and the LHP is nonoperating. The condenser temperature is then reduced to below that of the ammonia freezing point. The LHP is then successfully restarted.
\end{abstract}

\section{Introduction}

The loop heat pipe (LHP) with ammonia working fluid is a common heat transport device used in spacecraft. There are many publications outlining the basic operation of a LHP (Ref. 1). There has been some work on freezing of a LHP radiator with application to the microgravity environment, but none on freezing for the lunar gravity environment, commonly taken as one-sixth that of Earth (Ref. 2). Since partial gravity is available, this novel concept uses this gravity to drain the condenser of working fluid. There appears to be no reason why this concept cannot also work in microgravity, but this remains to be proved through testing. Once empty, the condenser tubes do not have to withstand the stress generated by expansion of frozen ammonia upon thawing, a limiting case for the structural integrity of the tubing. The deleterious effects of expansion and contraction of the empty aluminum tubing and attached radiator hardware would still have to be considered, but are generally considered manageable with proper design and testing. Thus, more applied engineering work in materials and structures would be needed to verify this concept as appropriate for a particular mission. 
At the surface of the South Pole of the Moon, the environment is extremely cold. Shadows from the surrounding terrain could cause the absence of solar illumination on the spacecraft for a period of several days. During this time, the spacecraft heat rejection radiator may need to be turned off and not reject any heat. It is possible that any ammonia left in the condenser would freeze and form a blockage in the condenser. Later, when the radiator is restarted, the blockage would prevent vapor from moving through the condenser. Restart would not be possible, without some auxiliary heating method to melt the ammonia blockage.

Another option for surviving extreme cold environments is to use a different working fluid called propylene. Propylene freezes at about $-185^{\circ} \mathrm{C}$, much lower than ammonia which freezes at $-78{ }^{\circ} \mathrm{C}$. This is a common working fluid for robotic spacecraft that must survive cold environments. The environment and mission design of robotic spacecraft are unlikely to produce LHP temperatures below $-185^{\circ} \mathrm{C}$. In the rare case of environments that would actually produce LHP temperatures below $-185^{\circ} \mathrm{C}$, heater power would be required to maintain the radiator temperature above freezing. In this case, maintaining the LHP above $-185^{\circ} \mathrm{C}$, instead of above $-78{ }^{\circ} \mathrm{C}$, would require much less heater power, a definite advantage for spacecraft. However, the disadvantage of using propylene, instead of ammonia, is that it lowers the loop heat pipe performance by about one third. In fact, the South Pole lunar environment and mission design will most likely produce radiator temperatures even lower than $-185^{\circ} \mathrm{C}$ for several days. This method described here would lessen the heater power needed to keep the radiator warm, or obviate the need for thaw heaters if the thermal control approach were to allow the radiator to freeze.

A mini LHP was operated at room temperature to verify its integrity. A tilt test was done to compare LHP performance of the simulated gravity of the Moon to that of the baseline microgravity environment. Liquid nitrogen was then poured over the condenser to bring the temperature of the condenser below the freezing point of ammonia. Thermocouples placed on the outside of the LHP were monitored with a commercial data acquisition system. The LHP was tilted such that the gravity vector along the length of the tubing was one-sixth that of Earth. Dry ice was also placed on the compensation chamber (CC) in order to draw liquid into the CC.

The LHP used here was manufactured by Thermacore and delivered to Goddard Spaceflight Center (GSFC) in 1997. The LHP was shipped to Glenn Research Center (GRC) in 2002. In the summer of 2007, the LHP was tested at GRC as part of NASA's Exploration Technology Development Program. The LHP survived an approximate 10 year dormant period and appears to be in good working order. Although not a rigorous life test, this investigation is a good indication of the viability of the long term operability of LHP.

\section{Hardware Setup and Procedure}

The LHP was built in 1997 by Thermacore as one of the deliverables for a Small Business Innovative

Research (SBIR) contract number NAS5-97024. A small copper block attached to the evaporator supplied heat via a $500 \mathrm{~W}$ cartridge heater. The area of the copper block evaporator interface was $4.25 \mathrm{~cm}^{2}$. The outer evaporator diameter was $1.6 \mathrm{~cm}$. The condenser length was about $3.8 \mathrm{~m}$ and attached to a thin aluminum plate. A cooling coil was attached to the opposite side of the aluminum plate, through which a Propylene Glycol/water solution was circulated to control the condenser. More details of the LHP construction are available from the final report (Ref. 3).

Twenty copper-constantan thermocouples were attached at various locations along the LHP and within the copper block heater. Figure 1 shows the locations of these thermocouples. The condenser area is marked by the locations of thermocouple 9 through 14 . The evaporator is shown as thermocouples 4,5 , and 6 . The CC is marked by thermocouples 19 and 20 . The heater block has thermocouples 1,2 , and 3 attached to the outside. Fibrous insulation was used to shield the entire test article from the surrounding air. A Polyscience Model 5105P chiller was connected to the LHP to circulate the coolant. The coolant used was a 50/50 propylene glycol/water mix. 


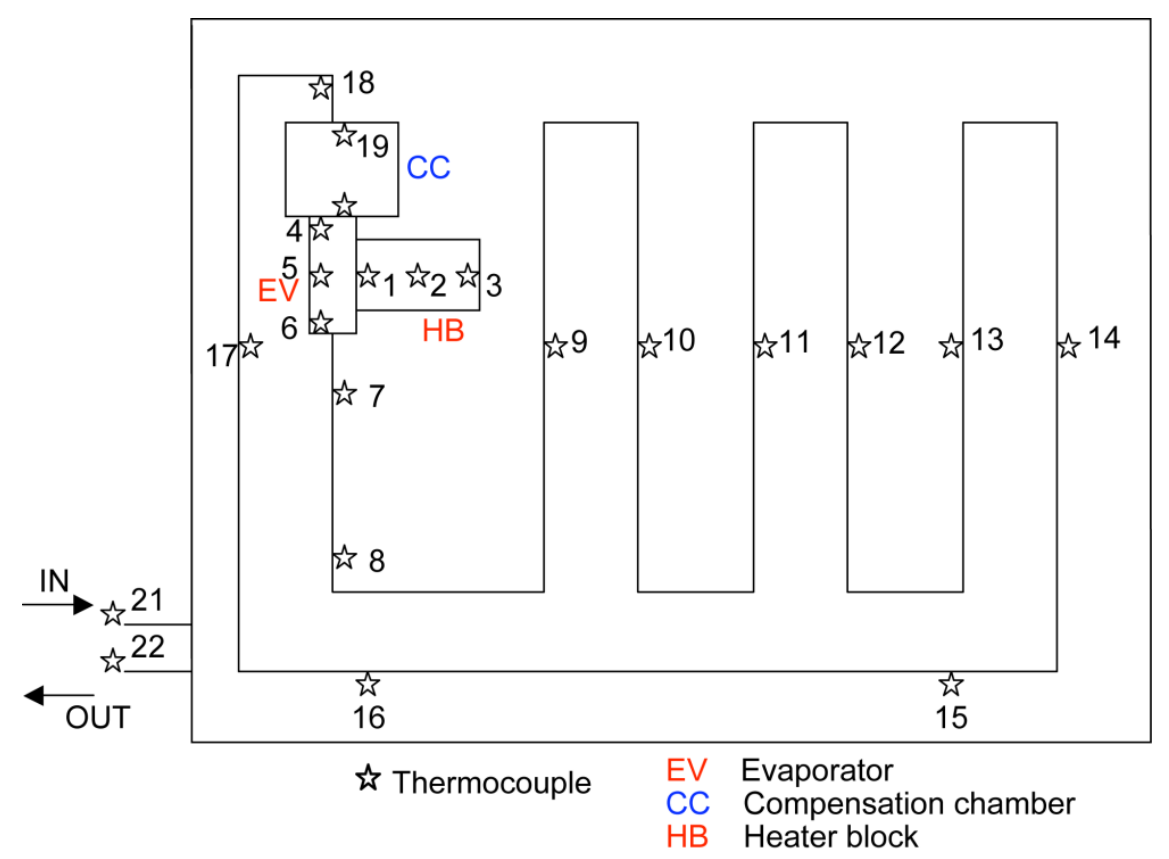

Figure 1.-Locations of test thermocouples.

There were three different insulations used in our setup. Two pieces of 2 in. thick Fibrex fiberglass insulation was placed on the bottom and top of the LHP. This provided 4 in. of fiberglass insulation on either side. A layer of 1 in. thick low density semi-rigid PVC foam insulation was placed between the LHP and the fiberglass. This was used because of its water resistant attribute. When the LHP was chilled to extreme cold temperatures, some moisture in the air condensed on the panel. This would have caused a problem, had the fiberglass insulation been in direct contact with this moisture. The data acquisition module was a combination of two separate modules. The Omega OMB-DAQ-56 was paired with the Omega OMB-PDQ1 expansion module. Each module allowed for 10 differential inputs, giving us a total of 20 differential channels. The accuracy of the data acquisition module was 0.015 percent of the reading 0.002 percent of range (exclusive of noise). The module was then plugged into a personal laptop computer where data was recorded. The electrical power source used for the heater block was an ISE Variac voltage source, model number 3PN1010B-DVM. It had an input of $120 \mathrm{VAC}$, single phase, and $50 / 60 \mathrm{~Hz}$. The output was 0 to $140 \mathrm{VAC}, 1.4 \mathrm{kVA}$, and $10 \mathrm{~A}$. A Fluke 77III multimeter was wired in between the voltage source and heater, such that power could be calculated from the measurement of current and applied voltage.

For the baseline test, the LHP was oriented in the horizontal position and a chiller was used to maintain the condenser at the desired temperature. Verifying that the LHP was still functioning correctly was vital to the outcome of the experiments. The LHP had not been operated prior to testing at GRC for almost 10 years. The goal of the verification test was to make certain that the LHP was still operating normally. A baseline test was run by Thermacore between 1996 and 1998. The LHP was insulated with 4 in. of fiberglass insulation on the top and bottom, and about 1 in. of Kaowool ceramic insulation around the sides. The chiller was set to $-10{ }^{\circ} \mathrm{C}$ at TC\#21, the input port for the coolant. Power input into the copper heater block ranged from 20 to $80 \mathrm{~W}$, in $10 \mathrm{~W}$ increments. Each power input step was allowed about 20 minutes to reach steady state, per Thermacore test requirements. The data was collected at five distinct locations around the LHP. Those locations were the evaporator wall, the vapor line, the condenser end, the liquid return line, and the compensation chamber cap.

For the tilt test, there were two orientations of the LHP. The first baseline test occurred with the LHP in the horizontal plane, simulating performance in microgravity. The second test occurred with the LHP at an angle. The LHP condenser was raised about $10 \mathrm{~cm}$ about the axis of the evaporator, with the angle from evaporator to condenser being $9.6^{\circ}$. This produced a gravity vector from the condenser to the 
evaporator which was equivalent to about one-sixth of Earth's gravity, as measured along the plane of the condenser. The chiller was used to maintain the condenser at the desired temperature.

For the freezing tests, crushed dry ice was placed on the condenser area of the LHP, near the locations of thermocouples 13 and 14. Liquid nitrogen was poured over the dry ice. The dry ice served to contain the liquid nitrogen at the desired location. The thermocouple temperatures were monitored carefully to ensure the condenser temperature dropped below the freezing point of ammonia $\left(-77^{\circ} \mathrm{C}\right)$. The freezing tests occurred with the LHP setup to simulate the lunar gravity environment. Dry ice was placed in contact with the $\mathrm{CC}$ to reduce the $\mathrm{CC}$ temperature to below the evaporator temperature and help draw liquid ammonia into the $\mathrm{CC}$. To get the $\mathrm{CC}$ as cold as possible, aluminum square tubing was wrapped in Kaowool insulation. Round grooves were cut out on one end of the tubing. The top half of the nylon block was removed to expose the $\mathrm{CC}$ wall. The tubing sat vertically on the nylon block. The tubing was packed with crushed dry ice and a steel weight was placed on top to keep contact between the CC wall and dry ice. A thermocouple was placed at the $\mathrm{CC}$ wall and temperatures as low as $-25{ }^{\circ} \mathrm{C}$ were consistently recorded at this location.

Once the CC had reached a cold steady state temperature, the condenser end of the LHP was frozen in order to simulate the freezing temperatures on the Moon. The top layers of insulation were removed. Crushed dry ice was placed on the last two lines at the condenser end (TC\#13 and TC\#14). Liquid nitrogen was then poured at consistent time intervals about every $30 \mathrm{sec}$, for about 4 minutes. The crushed ice served to contain the liquid nitrogen in the desired condenser area. This maintained condenser temperatures below the freezing point of ammonia for about 10 minutes. If there had been any liquid ammonia still left in the lines, it would have frozen in this time period. With the condenser end still below the freezing point of ammonia, the heater was turned on. No Propylene Glycol coolant was circulated to the panel at any time during the tests. It is interesting to note that dry ice alone was not sufficient to freeze the ammonia even though the temperature of dry ice is $-78^{\circ} \mathrm{C}$. The contact resistance of the sublimating carbon dioxide gas provided good thermal insulation between the dry ice and the condenser tubes.

The criteria for determining that the condenser was not blocked by frozen ammonia were:

1. TC\#7 and TC\#8 had to be cooler than the evaporator temperature. Otherwise, the LHP could not have been working.

2. The condenser end should be increasing in temperature, thus gaining heat from the evaporator.

3. The liquid return line temperature, TC\#16, is decreasing, indicating that cool liquid is moving from the condenser to the $\mathrm{CC}$.

If these conditions were met, it was a good indication that vapor was moving from the evaporator to the condenser and that the LHP had no frozen ammonia blockage in the condenser.

\section{Results and Discussion}

For the baseline test, conditions of the original test at the manufacturer were duplicated. Even though about 10 years had passed since the first test, the temperature-power profiles look very similar. Figure 2 shows the original 1997 test results taken from the final report (Ref. 3). Figure 3 shows the test results from GRC in 2007. Some discrepancy does exist, due to the fact that the thermocouple data acquisition system did not arrive with the LHP, and new thermocouples were attached to the test article at locations that were thought to be the same as during the original test. The attachment method was by aluminum tape during the GRC test and by clamps during the original tests. Also, the thermocouple numbering scheme for the testing at GRC is different than the original test. It should be noted that in Figures 2 and 3, the identification of the location is not only by number, but also by description. For the important parameter, the vapor to liquid return line temperature drop, both tests show similar values, about $10{ }^{\circ} \mathrm{C}$ at $80 \mathrm{~W}$. The absolute value of these temperatures is lower, and this could be due to more effective insulation in the GRC tests. For example, the original tests used 1 in. fiberglass insulation, and the GRC tests used 4 in. of fibrous fiberglass insulation. 


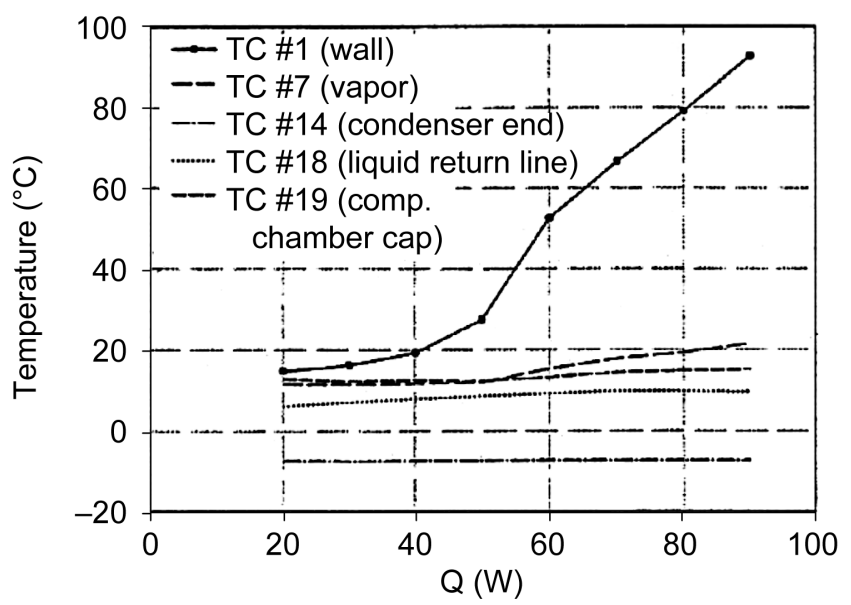

Figure 2.-Baseline test results from 1997.

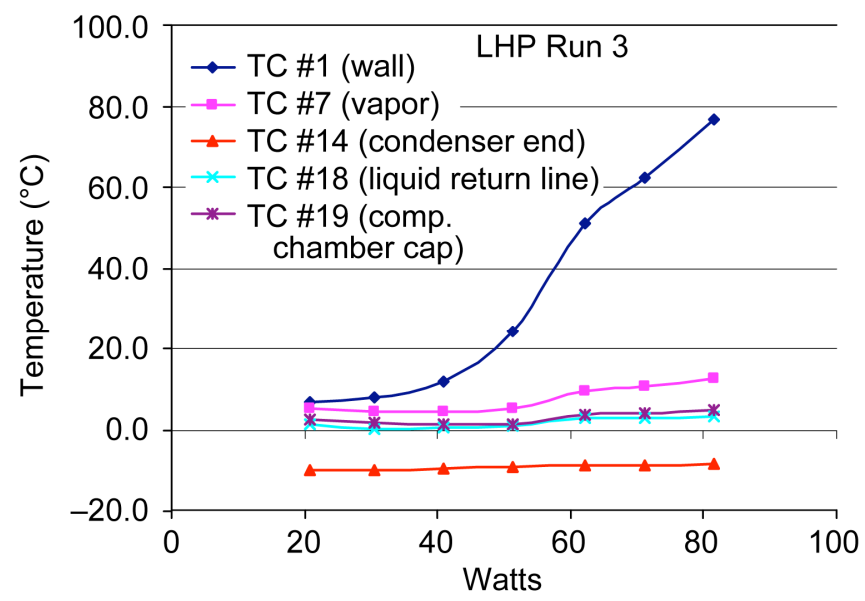

Figure 3.-Results of test performed in 2007 at GRC.

For the tilt test, the condenser was raised about $10 \mathrm{~cm}$. The LHP was left undisturbed overnight to allow the liquid to resettle. Note the scale has changed from Figures 2 and 3 such that the highest power level was only $50 \mathrm{~W}$ for these tests. Also, the condenser temperature changed from -10 to $-2{ }^{\circ} \mathrm{C}$, because the Polyscience chiller was not able to achieve the $-10{ }^{\circ} \mathrm{C}$ for the tilt tests. Results show similar temperatures when compared to Figure 3 , after considering the $8{ }^{\circ} \mathrm{C}$ temperature rise of the condenser temperature. For example, TC\#1 shows $33{ }^{\circ} \mathrm{C}$ in Figure 4 for $50 \mathrm{~W}$, and subtracting $8{ }^{\circ} \mathrm{C}$, makes the TC\#1 temperature close to that in Figure 3 for $50 \mathrm{~W}$, which is $23{ }^{\circ} \mathrm{C}$. This tilt test shows that the lunar gravity environment does not affect the performance of the LHP, as tested in this orientation, with this particular method of simulating the lunar gravity environment.

For the freezing tests, the condenser was again simulating lunar gravity. For results shown in Figure 5, "Freeze Run 2," liquid nitrogen was used to freeze the condenser end. There are a few main features in the graph that are worth pointing out. The first dip in the graph that is visible, TC\#19, is the chilling of the CC. Temperatures for TC\#7 and TC\#16 are higher than the $\mathrm{CC}$ and evaporator, indicating that warm liquid is possibly moving from the condenser into the evaporator as well as from the condenser into the CC. This is happening because of gravity and because of the lower vapor pressure in the $\mathrm{CC}$ created by the chilling of the CC. At the 9:50:24 mark, the CC temperature was stable, so the process to freeze the condenser began. One can see the extreme drop in temperature for TC\#14, which remained below $-77^{\circ} \mathrm{C}$ for about 10 minutes. 


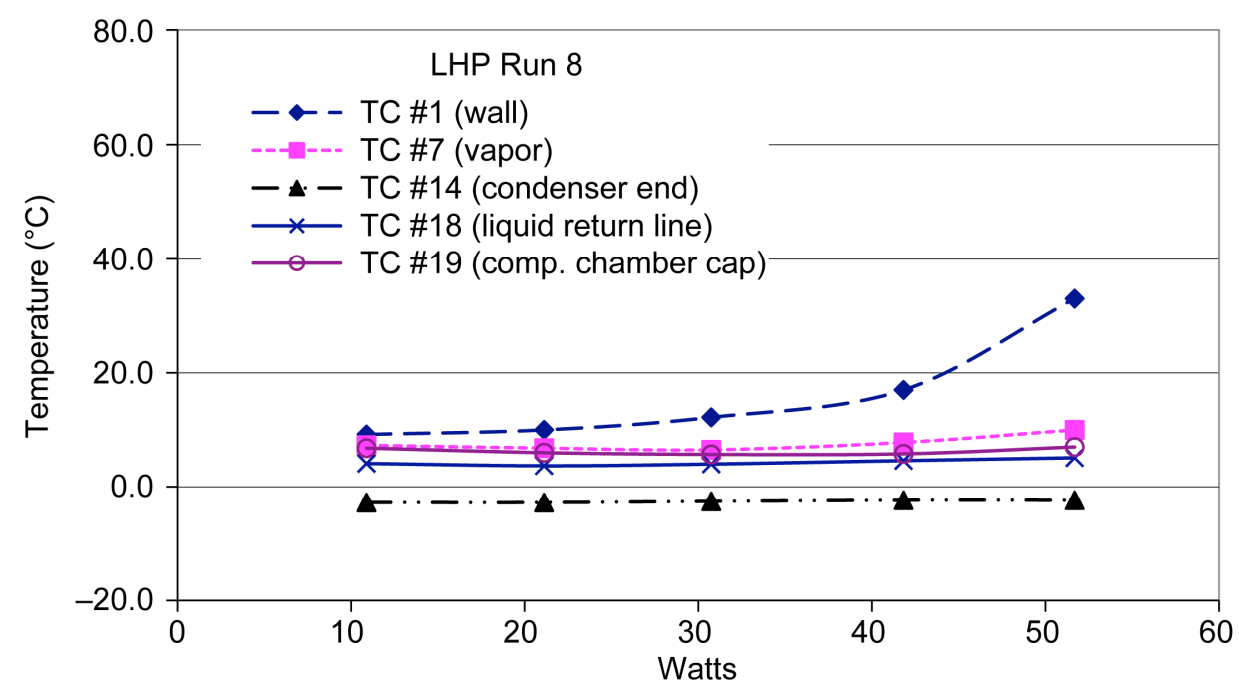

Figure 4.-Tilt test to simulate lunar gravity environment.

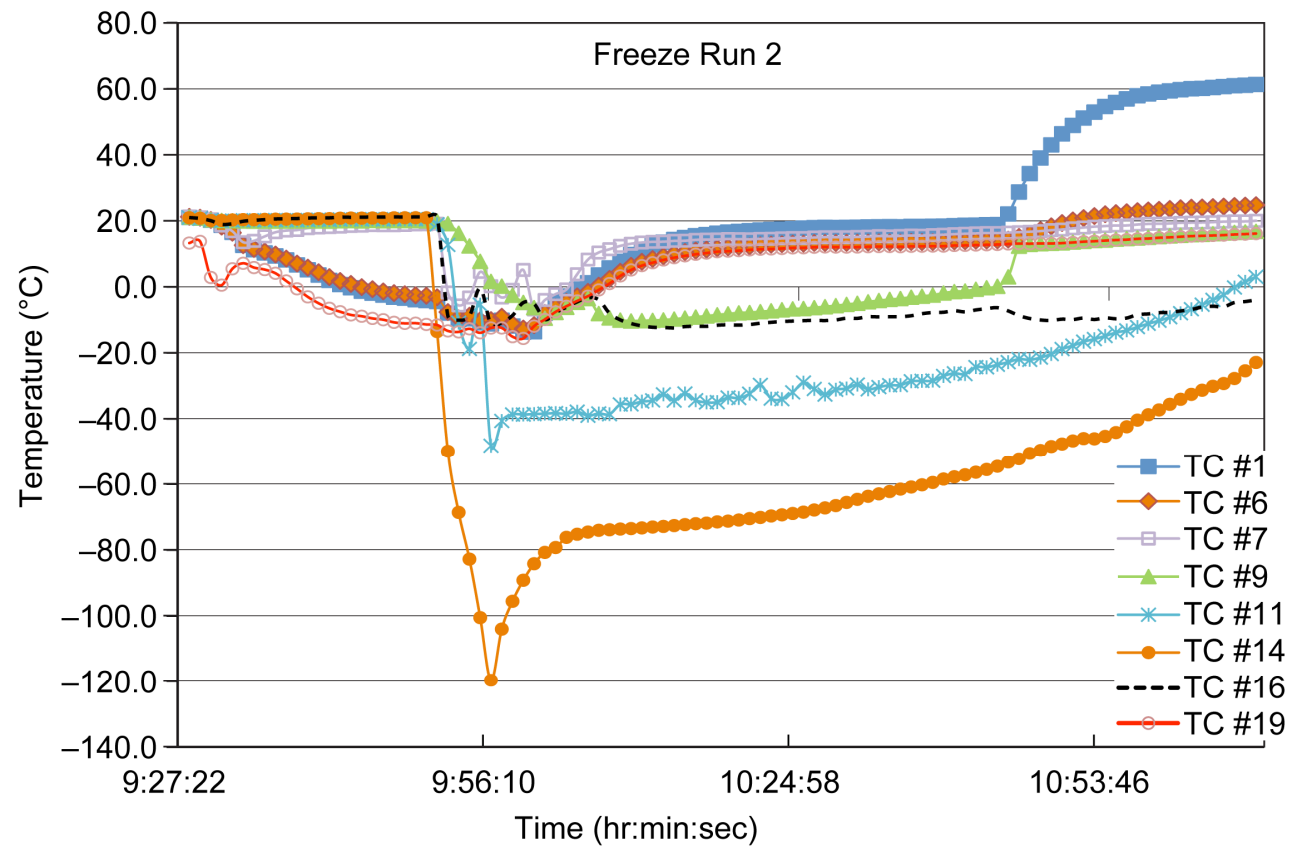

Figure 5.-Freezing test for $30 \mathrm{~W}$ initial.

The lowest temperature for TC\#14 was $-120^{\circ} \mathrm{C}$. Ten minutes is ample time for any liquid ammonia that might be in the condenser lines to freeze. At 10:00:24, $30 \mathrm{~W}$ was applied to the heater block. All temperatures near the evaporator and $\mathrm{CC}$ begin to rise at about the same rate. During this time, we did not see the LHP start due to fact that the vapor line temperature just downstream of the evaporator (TC\#7) was actually higher than the evaporator temperature (TC\#6). As discussed earlier, $30 \mathrm{~W}$ is sufficient to start the loop under normal conditions. However, it appears that this freezing condition requires larger startup heat than at room temperature conditions.

After it was apparent the loop would never start under these conditions, $60 \mathrm{~W}$ was applied to the heater block at 10:43:24. TC\#9 represents the midpoint of the condenser and begins to rise rapidly in a somewhat step increase profile. The condenser, TC\#14, does not change in a step profile, but continues rising at the same rate. It appears that the startup has produced some movement of a warm liquid front past the condenser location of TC\#9, but that the front has not reached the location of TC\#14. At 


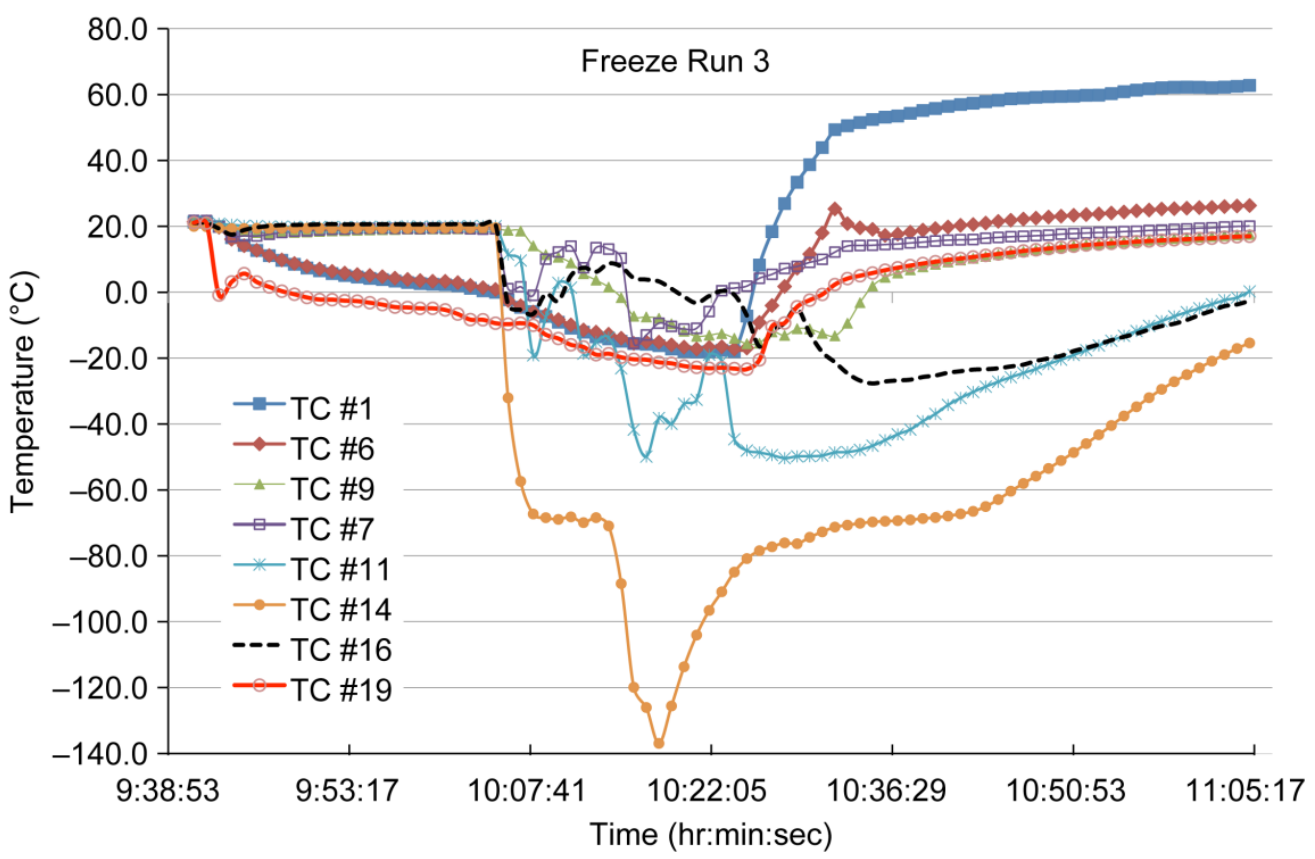

Figure 6.-Freezing test for $60 \mathrm{~W}$ initial.

10:47:24, TC\#6 rises above TC\#7, indicating there is vapor flow from the evaporator to the condenser. Since there appears to be heat transfer in the expected flow direction, it appears that the LHP began the startup process and there appears to have been no frozen ammonia blockage in the condenser.

Results for an additional freeze test are shown in Figure 6. For these tests, $60 \mathrm{~W}$ was applied initially, instead of $30 \mathrm{~W}$. The coldest condenser temperature was $-137.0^{\circ} \mathrm{C}$. The condenser portion of the LHP was maintained below $-77^{\circ} \mathrm{C}$ for approximately 12 minutes, which would have allowed sufficient time for the ammonia to freeze, if there had been any liquid ammonia in the condenser section. However, this conditioning method should leave no liquid ammonia in the condenser section. At 10:23:55, $60 \mathrm{~W}$ was applied to the heater block. At 10:48:00, the condenser temperatures began to rise rapidly, indicating that heat was being transferred from the evaporator to the condenser. Also, the liquid return line temperature, TC\#16, began to drop, indicating that cold liquid or vapor had begun moving from the condenser to the CC. Both of these trends indicate that the loop startup had begun. It therefore appears that there was no frozen ammonia blockage in the condenser. Similar temperature profiles were observed for Freeze Run 3 as were observed for Freeze Run 2 during startup.

\section{Conclusion}

There were several important accomplishments during this investigation: (1) A mini LHP was tested after approximately 10 years in storage and appeared to work normally, (2) this testing demonstrates that this novel method for surviving the cold lunar environment is practical, (3) this testing has shown that an ordinary LHP was robust enough to withstand temperatures well below the design temperature and well below the temperature of frozen ammonia, (4) it appears that larger startup heat is necessary under these conditions when compared to room temperature startup conditions, and (5) it was shown that the reduced gravity of the Moon does not affect the performance of this LHP, when compared to performance in a zero-gravity environment.

To implement this novel method of conditioning a LHP for a flight project, an actual flight LHP would require thermal cycle testing, with the number of cycles and temperature extremes determined by a consideration of both flight environments and expected failure mechanisms.

Further testing with larger LHP is recommended, since human-rated spacecraft have larger heat rejection requirements than demonstrated with this mini LHP. 


\section{References}

1. Jentung Ku, "Operating Characteristics of Loop Heat Pipes," SAE Paper 1999-01-2007, 1999.

2. Konstantin A. Goncharov, "Working Fluid De-Freezing in Radiator Manufactured on Base of Loop Heat Pipe," SAE Paper 2007-01-3199, 2007.

3. Dmitry K. Khrustalev, "Loop Heat Pipe for High Density Small Satellite Thermal Control Final Report,” Thermacore, Inc., 1998. 


\begin{tabular}{|c|c|c|}
\hline \multicolumn{2}{|c|}{ REPORT DOCUMENTATION PAGE } & $\begin{array}{l}\text { Form Approved } \\
\text { OMB No. 0704-0188 }\end{array}$ \\
\hline \multicolumn{3}{|c|}{$\begin{array}{l}\text { The public reporting burden for this collection of information is estimated to average } 1 \text { hour per response, including the time for reviewing instructions, searching existing data sources, gathering and maintaining the } \\
\text { data needed, and completing and reviewing the collection of information. Send comments regarding this burden estimate or any other aspect of this collection of information, including suggestions for reducing this } \\
\text { burden, to Department of Defense, Washington Headquarters Services, Directorate for Information Operations and Reports (0704-0183), } 1215 \text { Jefferson Davis Highway, Suite } 1204 \text {, Alrington, VA } 222022-402 \text {. } \\
\text { Respondents should be aware that notwithstanding any other provision of law, no person shall be subject to any penalty for failing to comply with a collection of information if it does not display a currently valid OMB } \\
\text { control number. } \\
\text { PLEASE DO NOT RETURN YOUR FORM TO THE ABOVE ADDRESSS. }\end{array}$} \\
\hline $\begin{array}{l}\text { 1. REPORT DATE (DD-MM-YYYY) } \\
01-06-2010\end{array}$ & $\begin{array}{l}\text { 2. REPORT TYPE } \\
\text { Technical Memorandum }\end{array}$ & 3. DATES COVERED (From - To) \\
\hline \multirow{3}{*}{\multicolumn{2}{|c|}{$\begin{array}{l}\text { 4. TITLE AND SUBTITLE } \\
\text { Investigation of Loop Heat Pipe Survival and Restart After Extreme Cold Environment } \\
\text { Exposure }\end{array}$}} & 5a. CONTRACT NUMBER \\
\hline & & 5b. GRANT NUMBER \\
\hline & & 5c. PROGRAM ELEMENT NUMBER \\
\hline \multirow{3}{*}{\multicolumn{2}{|c|}{$\begin{array}{l}\text { 6. AUTHOR(S) } \\
\text { Golliher, Eric; Ku, Jentung; Licari, Anthony; Sanzi, James }\end{array}$}} & 5d. PROJECT NUMBER \\
\hline & & 5e. TASK NUMBER \\
\hline & & $\begin{array}{l}\text { 5f. WORK UNIT NUMBER } \\
\text { WBS 736466.11.01.03.02.03.05 }\end{array}$ \\
\hline \multicolumn{2}{|c|}{$\begin{array}{l}\text { 7. PERFORMING ORGANIZATION NAME(S) AND ADDRESS(ES) } \\
\text { National Aeronautics and Space Administration } \\
\text { John H. Glenn Research Center at Lewis Field } \\
\text { Cleveland, Ohio 44135-3191 }\end{array}$} & $\begin{array}{l}\text { 8. PERFORMING ORGANIZATION } \\
\text { REPORT NUMBER } \\
\text { E-17103 }\end{array}$ \\
\hline \multirow{2}{*}{\multicolumn{2}{|c|}{$\begin{array}{l}\text { 9. SPONSORING/MONITORING AGENCY NAME(S) AND ADDRESS(ES) } \\
\text { National Aeronautics and Space Administration } \\
\text { Washington, DC 20546-0001 }\end{array}$}} & $\begin{array}{l}\text { 10. SPONSORING/MONITOR'S } \\
\text { ACRONYM(S) } \\
\text { NASA }\end{array}$ \\
\hline & & $\begin{array}{l}\text { 11. SPONSORING/MONITORING } \\
\text { REPORT NUMBER } \\
\text { NASA/TM-2010-216068; HT2009-88509 }\end{array}$ \\
\hline \multicolumn{3}{|c|}{$\begin{array}{l}\text { 12. DISTRIBUTION/AVAILABILITY STATEMENT } \\
\text { Unclassified-Unlimited } \\
\text { Subject Category: } 18 \\
\text { Available electronically at http://gltrs.grc.nasa.gov } \\
\text { This publication is available from the NASA Center for AeroSpace Information, 443-757-5802 }\end{array}$} \\
\hline
\end{tabular}

\section{ABSTRACT}

NASA plans human exploration near the South Pole of the Moon, and other locations where the environment is extremely cold. This paper reports on the heat transfer performance of a loop heat pipe (LHP) exposed to extreme cold under the simulated reduced gravitational environment of the Moon. A common method of spacecraft thermal control is to use a LHP with ammonia working fluid. Typically, a small amount of heat is provided either by electrical heaters or by environmental design, such that the LHP condenser temperature never drops below the freezing point of ammonia. The concern is that a liquid-filled, frozen condenser would not restart, or that a thawing condenser would damage the tubing due to the expansion of ammonia upon thawing. This paper reports the results of an experimental investigation of a novel approach to avoid these problems. The LHP compensation chamber (CC) is conditioned such that all the ammonia liquid is removed from the condenser and the LHP is nonoperating. The condenser temperature is then reduced to below that of the ammonia freezing point.

The LHP is then successfully restarted.

\section{SUBJECT TERMS}

Loop heat pipe; Radiator freezing

\begin{tabular}{|c|c|c|c|c|c|}
\hline \multicolumn{3}{|c|}{ 16. SECURITY CLASSIFICATION OF: } & \multirow{2}{*}{$\begin{array}{l}\text { 17. LIMITATION OF } \\
\text { ABSTRACT } \\
\text { UU }\end{array}$} & \multirow{2}{*}{$\begin{array}{l}\text { 18. NUMBER } \\
\text { OF } \\
\text { PAGES } \\
14\end{array}$} & \multirow{2}{*}{$\begin{array}{l}\text { 19a. NAME OF RESPONSIBLE PERSON } \\
\text { STI Help Desk (email:help@sti.nasa.gov) } \\
\text { 19b. TELEPHONE NUMBER (include area code) } \\
\text { 443-757-5802 }\end{array}$} \\
\hline $\begin{array}{l}\text { a. REPORT } \\
\text { U }\end{array}$ & $\begin{array}{l}\text { b. ABSTRACT } \\
U\end{array}$ & $\begin{array}{l}\text { c. THIS } \\
\text { PAGE } \\
\text { U }\end{array}$ & & & \\
\hline
\end{tabular}



